\section{Berlin retreats in reactor row}

\section{Munlch}

RESEARCHERs in West Berlin breathed a sigh of relief last week as mayor Walter Momper (Social Democrat) gave in to pressure from Bonn and agreed to license quickly a nuclear research reactor at the Hahn-Meitner Institute (HMI). The research committee of the Bundestag had threatened to cut off all funds for new research projects in West Berlin if the licensing of the reactor did not move ahead.

Momper faced a difficult decision as his fragile coalition government includes the Alternative Liste (AL), whose members oppose the operation of all nuclear reactors, including research reactors. At first, he tried to satisfy Bonn's demands by agreeing to license the reactor by May 1990 (see Nature 341, 479; 12 October 1989). But Momper has now been forced to go further and give an assurance to Bonn that all members of the West Berlin Senate, including those from the AL, are in favour of the reactor. Research Minister Heinz Riesenhuber (Christian Democrat) responded last week with DM18.5 million ( $\$ 10$ million) over five years to the Hahn-Meitner Institute for a new programme in photovoltaics and solar energy.

The Research Ministry (BMFT) paid 90 per cent of the total cost of renovating the reactor - some DM150 million ( $\$ 84$ million). Riesenhuber and his conservative colleagues in the Bundestag feared that

licensing delays might drag on for so long that the reactor might have to be scrapped without ever having been used. The reactor will serve primarily as a neutron source for physicists, chemists and biologists, mostly from outside HMI.

The West Berlin mayor's change of heart came partly in response to changing political circumstances following the opening of the border with East Germany and the tremendous influx of refugees and visitors. West Berlin now needs more money than ever from the West German government, which already provides more than half of its budget.

But the problems of HMI may not be over yet, according to HMI spokesman Thomas Robertson. Despite Momper's assurances, Environment Senator Michaela Schreyer (AL) may still try to find a way to delay the licensing. One opportunity exists in uncertainty over where waste from the reactor will go.

Plans to dispose of the waste in the United States are affected by a US court decision that prohibits the transport by road of nuclear waste containing highly enriched uranium. HMI is negotiating with Dounreay in Britain for temporary storage rights but it is not certain that Schreyer will accept this alternative.

The sole candidate for the open directorship of HMI, Siegfried Grossmann, has said he will take the job only if the reactor is licensed in May on schedule.

Steven Dickman ENVIRONMENT

\title{
Victory recorded in Mono
}

\section{San Franclsco}

IN a sweeping victory for environmentalists, a California judge last week upheld a temporary restraining order forbidding the city of Los Angeles from diverting water from Mono Lake, a unique wildlife habitat in the Sierra Nevada mountains of northern California, and moreover compelling the city to return to the lake some of the water that had already been diverted from its feeder streams into local reservoirs.

The ruling reaffirms earlier legal decisions that the diversion of water from feeder streams threatened the very existence of the alkaline lake, which is a migratory and nesting haven for thousands of rare or endangered birds. A temporary restraining order was granted in June forbidding the Los Angeles Department of Water and Power (LADWP) from removing diverted water from the Mono basin until 31 March. (This date represents the end of the "runoff year", by which time the winter's snow in the mountains has melted.) In August, the LADWP was ordered to release water from a holding reservoir in the Sierras to raise the lake level to 6377 feet, a foot and a half above its present level.

In September, the LADWP, which receives about 17 per cent of its water from Mono Lake streams, asked the court to reconsider this ruling. But on 6 December Superior Court Judge Terrence $M$. Finney rejected the appeal, and provided explicit instructions governing the rate of release.

The legal tussle over Mono Lake has become one of California's most contentious environmental issues. Los Angeles has been diverting water from Mono Lake since 1941. In that time the lake level has fallen by 41 feet, and several state and federal government studies have indicated that at the present rate of consumption the lake's ecosystem will collapse early in the next century (see Nature 341, 478; 1989). Environmental groups have rallied to the defence of Mono Lake, whose rich population of algae and brine shrimp attracts many species of birds.

Robert Buderi
Speedy money from Volkswagen

Munich

THE Volkswagen Foundation of West Germany has announced a new programme to aid universities in East Germany. It will create a fund of DM10 million (\$5.6 million) which will be made available in grants to researchers in all fields of natural science, social science and the humanities. A scientific review board to be named by the foundation will assess the applications; the money should begin flowing next year.

The West German government has already announced closer scientific cooperation with East Germany, but the action of the Volkswagen Foundation is the first private initiative of its kind in the aftermath of the collapse of the Berlin Wall. Spokesman Werner Boder said that the foundation's programme, beyond its immediate beneficial effects, is intended to stimulate similar initiatives from others.

The Hannover-based Volkswagen Foundation is the largest private foundation in Europe for the support of science and technology, and in 1988 provided about DM150 million in grants, to research institutions all over the world. Last March, the foundation had already begun to support cooperative projects between researchers in East and West Germany; the first fruit of these efforts will be the publication of a critical edition of The History of Ancient Art, written by the historian Johann Joachim Winckelmann in 1764.

Steven Dickman HUMAN-POWERED FLIGHT \section{Helicopter hovers for a moment}

\section{San Francisco}

RELYING on the furious pedalling of Greg McNeil, an engineering student and a member of the US cycling team, students at the California Polytechnic State University in San Luis Obispo have achieved what they called an aeronautical first: a humanpowered helicopter. To the cheers of watching students, the ungainly Da Vinci III craft, built mainly from composite materials and plastics, rose at a noticeable tilt several inches into the air before crashing to the ground, breaking one rotor tip.

One purpose of the eight-year project, is to capture the $\$ 25,000$ Igor I. Sikorsy Award offered by the American Helicopter Society. But to win the prize, the Da Vinci III will have to stay aloft a full minute and rise three metres in the air.

In the meantime, the students hope to claim an award from the less fussy International Aeronautic Federation. The team is hoping to get offical documentation of a human-powered helicopter liftoff, but have not yet been able to confirm the requirement, which they think is a mere 5-10 seconds aloft.

Robert Buderi 